\title{
Accounting
}

\section{Analysis of cash holding on investment cash flow sensitivity in Indonesia}

\section{B. Yuliarto Nugroho ${ }^{a^{*}}$}

${ }^{a}$ Faculty of Administrative Science, Universitas Indonesia, Indonesia

CHRON I C L E A B S T RACT

\section{Article history:}

Received May 102020

Received in revised format May 152020

Accepted June 152020

Available online

June 152020

Keywords:

Cash Holding

External Financing

Financial Constraints

Investment-Cash Flow Sensitivity

\begin{abstract}
This study aims to examine the effect of cash holding and external financing on investment-cash flow sensitivity. The sample in this research is the firm of non-finance which was listed on the Indonesia Stock Exchange over the period 2008-2017. The sample in this study was divided into categories of financial constraint to determine the influence of both variables more clearly on firms with different financial conditions. The research method used panel data regression by using fixed effect model to estimate investment-cash flow sensitivity. This study found that cash holding had a positive and significant effect on investment-cash flow sensitivity. Furthermore, external financing also had a positive and significant effect on investment cash flow sensitivity. The result of research refers that external financing is a substitute of internal funding to finance their investment; therefore, the companies have to manage finances well to their investment to enhance the value of the company and maximize shareholder wealth.
\end{abstract}

\section{Introduction}

In investing, companies can use internal funding sources and external funding sources. Internal funds can be obtained by the company using retained earnings and cash holding. Cash holding is an internal funding component that can be used to increase the company's cash flow. Cash holding is used to maintain the company's operational capability, pay off debt, pay dividends and invest without relying on external funding. It was concluded that cash holding allows companies to fund investments to prevent the emergence of high external funding costs. In line with this, Myers and Majluf(1984) suggested that companies rely more on internal funding sources because of the high cost of external funding. Regarding funding sources for investment, companies can also use external funding sources obtained by issuing bonds, issuing new shares and debt. External sources of funds tend to be used if the company's internal cash is insufficient to invest. In line with the pecking order theory which explains that companies are prioritized to use internal funding sources rather than external funding sources. Behind the benefits obtained from external funding, there are consequences for the company to bear the costs of internalizing shareholder investment decisions and having an obligation to pay debts. So, companies with massive debts will have limitations in maximizing the funds they have to make investments. Whited (1992) found that companies that have large debt are more financially limited and show higher investment-cash flow sensitivity; therefore, financially constrained companies must be able to rationalize the allocation of funds into assets that can maximize long-term returns for the company. The expensive cost of external capital sources causes companies to increase cash holding in recent decades because of an increase in business risk factors and company motivation in deciding the use of internal funds when investing. Because cash holding is one way to maintain company liquidity by keeping a nominal cash level. The research conducted by Bates et al. (2009) showed that the increase in cash holding in 500 * Corresponding author. 
non-financial companies in the United States increased from $10.5 \%$ in 1980 to $23.2 \%$ in 2006 . The growth in cash holding companies in Asia also increased quite sharply, where cash holding in 1996 was at $6.6 \%$ and increased by $12.1 \%$ in 2006 (Lee and Song, 2009). The action is intended so that the company can still invest and keep watch to avoid a crisis. Fazzari, Hubbard, and Petersen (1988), stated that internal funding through cash flow has a positive effect on investment decisions in financially constrained companies. Kaplan and Zingales (1997) and Cleary (1999) had different findings where investment-cash flow sensitivity is more sensitive for companies financially unconstrained. These conflicting results are due to the use of different criteria to identify financially constrained companies. Moyen's (2004) study found that when using Cleary Index and Kaplan and Zingale's criteria it was found that companies financially unconstrained were more sensitive to cash flow than companies financially constrained in investing. Conversely, when using classifications based on dividend payout, cash flow, and the criteria of Fazzari, Hubbard, and Petersen (1988), companies that are financially constrained are more sensitive to cash flow than companies financially unconstrained in investing. Whereas, S. Chen and H. Chen (2012) found that there was no significant relationship between financial constraint and investment-cash flow sensitivity. Empirical evidence in Indonesia is shown by Prihatmoko (2013) that there is a positive and significant effect of cash flow on capital investment. These results identify the existence of investment-cash flow sensitivity in manufacturing companies in Indonesia. Furthermore, Ramadhan and Nugroho (2017) found that cash holding is much higher in the financially constrained companies. Also, Kim (2014) shows that cash holding moderates the effect of cash flow on capital expenditure which is indicated by a significant adverse impact. Cash holding will be used if other funding sources including cash flow are insufficient to fund the company's investment decisions. Kim (2014) found that external financing has a significant negative effect on investment-cash flow sensitivity. Previous research on investment-cash flow sensitivity has mixed results due to differences in grouping companies when conducting research. The difference in findings regarding the relationship of financial constraints with investment-cash flow sensitivity has been debated to date because there is no standard measure of financial constraint parameters. Also, researchers are motivated by the relevance of investment-cash flow sensitivity as an economic indicator that requires more convincing and accurate empirical evidence. Researchers were also driven by the decline of the Indonesian economy in recent years due to the weakening of the manufacturing industry, where the manufacturing industry contributed significantly to sustaining the pace of the national economy. Thus, there needs to be a well-performing sector to encourage economic growth. One of the determinants of a good performing company is seen from the capital; therefore, researcher wants to do more in-depth research about investment-cash flow sensitivity and to extend the relationship of cash holding and investment cash flow sensitivity.

Research on investment-cash flow sensitivity in Indonesia is still relatively rare. Therefore, it is necessary to have holistic measurements in measuring financial constraints and investment-cash flow sensitivity. This study aims to contribute to the existing literature on the impact of cash holding and external financing on investment-cash flow sensitivity using the case of Indonesia. This study discusses changes in investment-cash flow effectiveness, using capital expenditure as the dependent variable. Furthermore, Tobin's Q (growth opportunity), cash flow, and cash holding became independent variables in this study. This study uses a sample of non-financial companies listed on the Indonesia Stock Exchange in the period 2008-2017. The period was chosen to see the macroeconomic dynamics and the influence of the factors used during the research period to become a consideration or suggestion for companies to invest in performing well and encourages industrial and economic performance. Researchers use a sample of non-financial companies because this industry influences economic growth. Also, the financial sector industry, especially banks, has different financial reports and different levels of debt and the minimum capital requirements that must be met by financial companies.

\section{Literature Review}

In the corporate finance literature, the notion of investment means capital expenditure or investment in fixed assets such as land or property, buildings, and equipment (Fazzari et al., 1988). According to Syamsuddin (2001), investment means capital expenditure or expenditures made by the company in the hope that the spending will provide benefits or results in the long run. It can be concluded that investment is defined as a source or asset that will generate corporate income. The aim of the company is to make capital expenditures to increase company value and benefit for more than one year. The basic motivation of capital expenditure by the company is to expand, purchase or replace fixed assets or look for benefits that may be less tangible in the long term. The company's capital investment is determined by cash flow and growth opportunities. Realization of investment requires the availability of sufficient cash to meet capital expenditure needs. Cash flow is one of the internal funding sources of a company Fazzari et al. (1988). The use of cash flows as an internal funding source in investing is prioritized in a company due to constraints in obtaining external funding. The use of external funding in the form of bank loans requires a long and costly procedure. Also, companies must also have guarantees that can convince creditors to provide loans, either in the form of company value, company profits, or company assets (Gilchrist \& Himmelberg, 1995). Cash flow is a cheap source of funding compared to the use of external income sources such as bank loans and the issuance of new shares. The availability of cash flow is vital for the company because cash is used in the short-term and long-term financing of the company. Companies that have significant cash flows and access to external funding can easily invest and are not affected by fluctuations in the company's cash flows. This is because companies can use internal and external funding alternatives to invest. This shows that investment-cash flow sensitivity is low because companies have many options in financing for investments. Unlike companies that have relatively 
little cash flows and barriers to accessing external funding that have investment-cash flow sensitivity is higher (Fazzari et al., 1988). Growth opportunities in this study use Tobin's q proxy where Tobin's q reflects the market value of the company's assets and replacement value for assets. The ratio of $q$ is the ratio of the company's value which is hypothesized to increase the cost of company capital (capital expenditure), because the higher q ratio reflects the greater opportunity to grow and the higher the cost of equity capital (capital expenditure) that must be spent. Bodie et al. (2009) stated that a high q value (qi $>1$ ) indicates the company's market value is higher than the cost of replacing the actual assets of the company. This means that there are assets that are not reflected in market value. A high q ratio encourages companies to invest more capital because the investment is worth more than the price paid to get it; however, this condition will not last long because the competing company will always try to replicate the asset and push the q value to the actual market value of the company (qi $=1$ ). Conversely, a low $q$ value of one $(0<$ qi $<1)$ indicates that the company is valued by the market with a value lower than the actual cost of replacing the company's assets. This shows that the return of investment cannot cover the cost of capital. Tobin's q has an important role in financial activities or interactions with the company. For q to be used, it is necessary to make precise measurements of the company's market value and the replacement cost of the company's assets. The estimated market value of the company can be done by summing the value of securities that have been issued by the company, such as stocks and bonds. Difficulties in determining the market value of the equipment used will emerge when evaluating replacement costs. Moreover, research and development costs and marketing costs create values that are intangible so that it will be difficult to measure.

Based on research by Fazzari, Hubbard, and Petersen (1988), it was found that companies that have higher Tobin q values will have easier access to obtain more significant amounts of external income and also increase the opportunity for corporate investment. Degryse and de Jong (2006) found that companies with low growth prospects (low q value), have higher investment cash-flow sensitivity. Conversely, companies with high growth prospects (high q value), have lower investment cash-flow sensitivity while the research of $\mathrm{H}$. Chen and S. Chen (2012) suggests that error measurements with Tobin's q measurements cannot provide complete measurements in the effect of investment-cash flow sensitivity. Cash holding is another internal funding component that can be used to increase the company's cash flow (Almeida \& Campello, 2010). Bao, Kam, and Weining (2012) define cash holding as the amount of cash equivalent cash contained in the balance sheet against total assets. Cash holding is used to maintain the company's operational capability, pay off debt, pay dividends and invest without relying on external funding. It can be concluded that cash holding allows companies to fund investments to prevent the emergence of high external funding costs from increasing company financing. There are several benefits the company has when holding cash. Cash holding reduces the possibility of financial difficulties because there are cash reserves to deal with unexpected losses or obstacles to obtaining external funding. Also, cash holding also allows companies to implement optimal investment policies even when companies experience financial constraints. If you do not have cash, when there are constraints funding will force companies to lose the opportunity to take investment projects. Another benefit of having a cash holding contributes to minimizing external funding costs or liquidating existing assets. This is because cash holding acts as a buffer between funding sources and use of funds. However, companies need to consider the placement of funds, because if the cash holding is too large or too small, it will disrupt the financial stability of the company. If the company has too much cash, the company will be considered liquid, but it is considered inefficient in using its funds. This allows for uncontrolled buildup of cash (Fahmi, 2013), because excess cash holding is easy to divert its use to destinations that are not by the interests of shareholders. In addition, excess cash holding can provide flexibility to avoid costs arising from underinvestment. It can be concluded that the company's activities run optimally, cash should be well-planned. Kim (2014) found that corporate cash holding damages investment-cash flow sensitivity. In addition to utilizing internal funding sources, companies can use external funding sources in the form of bank loans and equity issuance. External funding in the form of bank loans is one that is quite attractive for companies in investing. This is because the company benefits from a tax shield (Brealey, Myers, and Allen, 2006). Consideration of costs that must be incurred in obtaining funding sources which result in the order in funding. Myers and Majluf(1984) revealed the preference for the sequence of funding sources as follows, Debt, preferred stock, (common stock). Debt is one component of external funding that is favored by companies. Even so, excessive use of debt will have a negative impact on the company, especially during an economic recession. During an economic recession, the government will attempt to restore the stability of financial conditions by increasing loan interest rates. This certainly will have a bad impact on companies that have high leverage because borrowing costs will increase from before, while the level of profitability of the company does not increase which is in line with the increase in loan interest. Also, the use of debt as a source of excessive funding will adversely affect the company's growth. Lang et al. (1996) stated that high debt levels can make a company's financial growth decline because of the effects of poor liquidity due to excessive bank loans. The use of funding from excessive bank loans, most of the cash obtained will be used to finance the loan, not for investment. For financially constrained companies, it can cause the company to experience debt repayment failure with creditors.

\section{Methodology}

The research approach used in this study is quantitative approach. This study uses panel data that combines cross-section data and time series data. The data used came from domestic and foreign publications, journals, survey results, and others. Sampling in this study was carried out using a purposive sampling method, where samples were chosen according to the suitability of sample characteristics and specified sample selection criteria. This study uses 116 samples of non-financial companies listed on 
the Indonesia Stock Exchange 2008-2017. The research method used is panel data regression by using the fixed effect model in estimating the regression model (Gujarati, 2008).

The following empirical model equation model is applied to compare the effect of cash holding and external financing on investment-cash flow sensitivity.

\begin{tabular}{|c|c|c|}
\hline \multicolumn{3}{|c|}{ 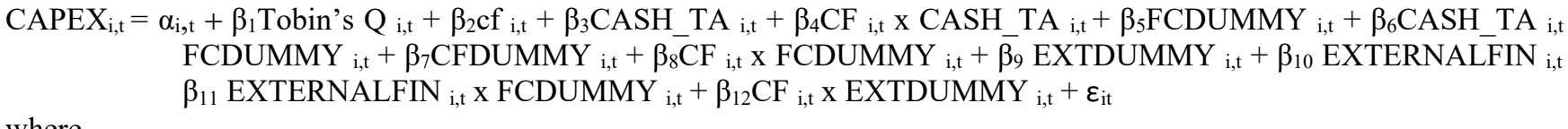 } \\
\hline $\begin{array}{c}\text { where, } \\
\alpha_{i, t}\end{array}$ & $=$ & intercept company $i$ in period $t$ \\
\hline$\beta n$ & $=$ & coefficients for each independent variable \\
\hline$C A P E X_{i, t}$ & $=$ & $\begin{array}{l}\text { capital expenditure on company } i \text { in period } t \text {, calculated from the ratio } \\
\text { between capital expenditure (capex) in period } t \text { with the total assets of the } \\
\text { previous period }\end{array}$ \\
\hline $\operatorname{TOBINQ}_{i, t}$ & $=$ & $\begin{array}{l}\text { annual company growth opportunities are measured by the total market value of firm } \\
\text { divided by total asset value }\end{array}$ \\
\hline$C F_{i, t}$ & $=$ & $\begin{array}{l}\text { company investment cash flow } i \text { in period } t \text {, calculated from cash flow ratio (EBITDA } \\
+ \text { Depreciation }+ \text { Amortization) with previous total assets }\end{array}$ \\
\hline CASH_TA $A_{i, t}$ & $=$ & $\begin{array}{l}\text { the company } i \text { holding cash rate in period } t \text {, calculated from the previous period cash } \\
\text { equivalents divided by the company's total assets two previous periods }\end{array}$ \\
\hline CFi,t $x$ CASH_TA $A_{i, t}$ & $=$ & $\begin{array}{l}\text { interaction variable between cash flow and company } i \text { cash holding in period } t \text {, } \\
\text { calculated from cash flow (EBITDA }+ \text { Depreciation }+ \text { Amortization) multiplied by cash } \\
\text { equivalent with total assets }\end{array}$ \\
\hline$F C D U M M Y_{i, t}$ & $=$ & $\begin{array}{l}\text { company dummy financially constraint } i \text { variable in period } t \text {, financially constrained } \\
\text { firms worth } 1 \text { and financially unconstrained firms are worth } 0\end{array}$ \\
\hline CASH_TAi,t $x$ FCDUM & & $\begin{array}{l}\text { the interaction variable between cash holding and company } i \text { dummy financial } \\
\text { constraints variable in period } t \text {, is assessed by principal component analysis if the } \\
\text { company has a high value of } 1 \text { and has a value of } 0 \text { if it has a low value. }\end{array}$ \\
\hline$C F D U M M Y_{i, t}$ & $=$ & $\begin{array}{l}\text { the dummy variable of company } i \text { cash flow in period } t \text {, positive cash flow is } 1 \text { and } \\
\text { negative cash flow is } 0\end{array}$ \\
\hline$C F i, t \times F C D U M M Y_{i, t}$ & $=$ & $\begin{array}{l}\text { the interaction variable between cash flow and the dummy variable financial constraints } \\
\text { of company } i \text { in period } t \text {, calculated from cash flow (EBITDA }+ \text { Depreciation }+ \\
\text { Amortization) with dummy financial constraints }\end{array}$ \\
\hline$E X T D U M M Y_{i, t}$ & $=$ & $\begin{array}{l}\text { positive and negative external funding dummy variable company } i \text { in period } t \text {, positive } \\
\text { external financing is } 1 \text { and external financing negative is } 0\end{array}$ \\
\hline EXTERNALFIN $N_{i, t}$ & $=$ & company external funding $i$ in period $t$, calculated from the amount of debt and equity \\
\hline$E_{X T E R N A L F I N}{ }_{i, t} x$ & & the interaction variable between external funding and company $i$ dummy financial \\
\hline$F C D U M M Y_{i, t}$ & $=$ & $\begin{array}{l}\text { constraints variable in period } t \text {, calculated from the amount of debt and equity with } \\
\text { dummy financial constraints }\end{array}$ \\
\hline$C F_{i, t} \times E X T D U M M Y_{i, t}$ & $=$ & $\begin{array}{l}\text { the interaction variable between cash flow and the dummy variable of the company's } \\
\text { external funding in period } t\end{array}$ \\
\hline$\varepsilon_{i, t}$ & & error factor \\
\hline
\end{tabular}

Furthermore, the sample in this study was divided into the category of financial constraints to find out more clearly the influence of these two variables on companies with different financial conditions. Financial constraint is defined as the company's limitations in obtaining additional capital to make business investments both from within the company and outside the company (Fazzari, Hubbard, and Petersen, 1988). According to Hennessy and Whited (2007), financial constraints are circumstances in which companies are faced with profitable investment opportunities, but the company experiences financial limitations in external funding. Kaplan and Zingales (1997) define financial constraints as a condition of a company facing a difference in the form of costs between internal and external funding. In general, financial constraints are defined as the condition of a company's financial limitations in financing its investment projects using external funding sources. The measurement of the level of financial constraints carried out in this study is to use principal component analysis. In the principal component analysis, the researcher integrates various types of measurements, namely, dividend probability, wwindex, bond rating, and size in one universal size. The probability of a dividend payment is the probability predicted from the annual logistic regression model used by Denis and Osobov (2008). The dependent variable in this logistic regression is a dummy dividend payment. If the company 
pays dividends in year $\mathrm{t}$ is worth one; on the contrary, if it does not pay dividends in year $\mathrm{t}$ equal zero. Independent variables are market to book ratio, the percentage of total company assets, EBIT before tax divided by total assets, retained accounting divided by book equity and company size. The result is if the probability of a dividend payment is high, it can be said that the company is financially unconstrained. The result is if the probability of a dividend payment is high, it can be said that the company is financially unconstrained. Furthermore, Whited and $\mathrm{Wu}$ introduced an index of financial constraints defined as shadow costs related to an increase in new equity, or can be interpreted as a slice between external funding and internal cash flows (Whited and $\mathrm{Wu}, 2006$ ). If the index level is high, it is said to be a financially constrained company. The Whited-Wu index is formulated as follows:

$$
\text { wwindex }=-0,091 \mathrm{CF}_{\text {it }}-0,062 \mathrm{DIVPOS}_{\mathrm{it}}+0,021 \mathrm{TLTD}_{\mathrm{it}}-0,044 \mathrm{LNTA}_{\mathrm{it}}+0,102 \mathrm{ISG}_{\mathrm{it}}+0,035 \mathrm{SG}_{\mathrm{it}}
$$

where CF is cash flow, DIVPOS is a dummy dividend payment, TLTD is a debt to asset ratio, LNTA is a natural total asset logarithm, and ISG is an industry sales growth ratio. The result, if the index level is high, is said to be a financially constrained company. Based on the bond rating, the measurement of financial constraints uses a dummy variable. Companies that get $\mathrm{C}$ and below $\mathrm{C}$ levels in year $\mathrm{t}$ are considered equal to zero, if the company's rating in year $\mathrm{t}$ above $\mathrm{C}$ is rated as 1 . Thus, if the company has a good bond rating then the company is said to be financially unconstrained (Gilchrist and Himmelberg, 1995; Almeida, Campello and Weisbach, 2004). Gilchrist and Himmelberg (1995) and Almeida, Campello and Weisbach (2004) said that firm size is used as a measure of financial constraints. Small companies are said to be financially constrained, if the company has a large and mature size it is said to be financially unconstrained. Previous research conducted by Kim (2014) stated that the relationship of investment-cash flow sensitivity and cash holding is in the company financially constrained. Also, a significant relationship was found between cash holding and external financing with investment-cash-flow sensitivity. In line with the framework of thinking that has been done by Kim (2014) and the previous researchs, the hypothesis proposed in this study are:

$$
\begin{aligned}
& \mathrm{H}_{1} \text { : Cash holding has a significant negative effect on investment-cash flow sensitivity. } \\
& \mathrm{H}_{2} \text { : External financing has a significant negative effect on investment-cash flow sensitivity. }
\end{aligned}
$$

\section{Result and Discussion}

\subsection{Results}

This study measures the sensitivity of independent variables used including cash holding, Tobin's q, and cash flow and external financing to investment cash flow sensitivity that uses capital expenditure as a proxy. In this study, there is a sample distribution based on financial constraints parameters with principal component analysis. In the principal component analysis, the researcher integrates various types of measurements, namely, dividend probability, wwindex, bond rating, and size in one universal measure. The results of the principal component analysis can be seen in the Table 1 .

\begin{tabular}{|c|c|c|c|c|}
\hline & Comp1 & Comp2 & Comp3 & Comp4 \\
\hline Eigenvalue & 3.0218 & 0.0273 & 0.0155 & 0.0031 \\
\hline Proportion & 0.985 & 0.009 & 0.005 & 0.001 \\
\hline Cumulative & 0.985 & 0.994 & 0.999 & 1.000 \\
\hline \multicolumn{5}{|c|}{ Principal Component (eigenvectors) } \\
\hline Variable & PC1 & PC2 & PC3 & PC4 \\
\hline pred div & 0.120 & 0.980 & 0.042 & 0.154 \\
\hline bond rating & 0.012 & -0.046 & 0.999 & 0.011 \\
\hline size & 0.991 & -0.126 & -0.018 & 0.034 \\
\hline wwindex & -0.053 & -0.148 & -0.017 & 0.987 \\
\hline
\end{tabular}

Table 1

Results of Principal Component Analysis

Source: Output Minitab 16 (processed)

Table 1 shows the results of the principal component (Comp1) having eigenvalue 3.0218 and describing $98.50 \%$ of the total variation of measurements. The first component eigenvectors (PC1) have a positive sign for pred_div, bond rating, and size, as well as a negative sign for wwindex. Based on these results, it can be said that the first component ( $\overline{\mathrm{PC}} 1)$ is inversely proportional because the company financially constrained has a lower dividend probability, a higher Whited-Wu index, a lower bond rating, and a smaller company size. Thus, the researcher multiplies the first component (PC1) with a negative sign to measure the level of financial constraints (fin_cons). In classifying financially constrained companies, this study employs the study of Kim (2014) by classifying into four quartiles based on the level of financial constraints (fin_cons). If it is in the lowest quartile, the company is financially constrained. The quartile results from the level of financial constraints (fin_cons) can be seen in the following Table 2. Table 2 shows that the lowest quartile value of financial constraints is 26,743. Companies with financial constraints (fin_cons) below this value are classified as financially constrained companies, while companies with fin_cons above 26,743 are classified as financially unconstrained companies. After it is known that companies are constrained and unconstraint, then a regression is made to compare the effects of cash holding and external financing on cash flow sensitivity. 


\section{Table 2}

Results of quartile

\begin{tabular}{lccc}
\hline Variable & Q1 & Median & Q3 \\
\hline fins_cons & 26,743 & 28,024 & 29,403 \\
\hline Source: Output Minitab 16 (processed) & & &
\end{tabular}

Table 3 shows the results of regression of the data panel using the fixed effect method (FEM). Significant testing was obtained on cash flow variables (CF), cash holding (CASH_TA), external funding (EXTERNALFIN), and interaction variables between cash flow and external financing dummy $(\mathrm{CF} \times \mathrm{EXTDUMMY)}$. CF variable has a significant positive effect on CAPEX with a correlation coefficient of 0.135 . This result is interpreted in that if cash flows increase by 1 percent, on average the capital expenditure (capex) realized by non-financial companies will increase by 0.135 percent. Statistically, the influence of CF on CAPEX in previous studies which also used similar models also produced a strong correlation coefficient, as did Kim's research (2014). The positive cash flow coefficient on capital expenditure shows that non-financial companies in Indonesia in investing tend to use internal cash.

\section{Table 3}

Results of Regression Panel Data of FEM

\begin{tabular}{|c|c|c|c|c|}
\hline Variable & Coefficient & Std. Error & t-stat & Prob \\
\hline $\mathrm{C}$ & 0.004 & 0.044 & 0.098 & 0.922 \\
\hline $\mathrm{CF}$ & 0.135 & 0.065 & 2.063 & $0.039 * *$ \\
\hline TOBINQ & 0.000 & 0.000 & 0.226 & 0.821 \\
\hline CASH_TA & 0.021 & 0.009 & 2.387 & $0.017 * *$ \\
\hline $\mathrm{CF} \times \mathrm{CASH}$ CA & -0.021 & 0.016 & -1.301 & 0.194 \\
\hline FCDUMMY $=0 \quad$ EXTDUMMY $=1 \quad$ CFDUMMY $=0$ & 0.060 & 0.048 & 1.244 & 0.214 \\
\hline FCDUMMY=0 EXTDUMMY=1 CFDUMMY=1 & 0.053 & 0.045 & 1.184 & 0.237 \\
\hline FCDUMMY $=1$ EXTDUMMY $=0$ CFDUMMY $=0$ & 0.007 & 0.032 & 0.223 & 0.823 \\
\hline FCDUMMY=1 EXTDUMMY=0 CFDUMMY=1 & 0.047 & 0.049 & 0.949 & 0.343 \\
\hline FCDUMMY=1 EXTDUMMY=1 CFDUMMY=0 & 0.053 & 0.043 & 1.225 & 0.221 \\
\hline FCDUMMY=1 EXTDUMMY=1 CFDUMMY=1 & 0.054 & 0.044 & 1.224 & 0.221 \\
\hline $\mathrm{CF} \times \mathrm{FCDUMMY}$ & -0.093 & 0.099 & -0.937 & 0.349 \\
\hline $\mathrm{CF} \times \mathrm{EXTDUMMY}$ & -0.135 & 0.068 & -1.977 & $0.048 * *$ \\
\hline CASH_TA $\times$ FCDUMMY & -0.102 & 0.099 & -1.034 & 0.301 \\
\hline EXTERNALFIN & $1.41 \mathrm{E}-06$ & $2.92 \mathrm{E}-07$ & -4.841 & $0.095^{*}$ \\
\hline EXTERNALFIN $\times$ FCDUMMY & 0.096 & 0.099 & 0.970 & 0.332 \\
\hline
\end{tabular}

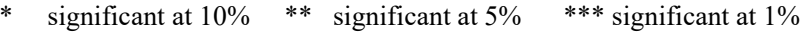

The cash holding variable (CASH_TA) has a positive relationship with a coefficient of 0.021 and has a significance level at the level of 1 percent. This result is interpreted if the holding cash increases by 1 percent, then the average capital expenditure realized by non-financial companies will increase by 0.021 . Furthermore, to prove whether weakening the positive influence of cash holding on capital expenditure is done by looking at the direction of the relationship between moderating variables $(\mathrm{CF} \times$ CASH_TA) and the dependent variable (CAPEX). If the correlation coefficient is negative, then this indicates that the moderating variable is proven to weaken the positive influence of the variable (CASH_TA) on the dependent variable (CAPEX). The results of the correlation coefficient of the moderating variable $\mathrm{CF} \times \mathrm{CASH}$ TA were negative but did not significantly affect CAPEX. This shows that cash flow is not relevant enough to control the effect of cash holding on capital expenditure. Positive relationships are obtained by external funding variables (EXTERNALFIN) with a coefficient of $1.41 \mathrm{E}-06$ which is significant at the 10 percent level. This result is interpreted if external financing increases by 1 percent, then on average the capital expenditure realized by non-financial companies will increase by $1.41 \mathrm{E}-06$. Another moderating variable is that the interaction variable between cash flow and dummy external financing has a negative and significant correlation coefficient. These results indicate that cash flows are proven to weaken the positive effect of the EXTDUMMY variable on investment-cash flow sensitivity. The t-test results show the CF $\times$ EXTDUMMY variable. If the correlation coefficient is negative, then this indicates that the moderating variable is proven to weaken the positive influence of the other EXTDUMMY variables on the dependent variable (CAPEX).

\subsection{Discussion}

In this study it was found that there was no significant relationship between financial constraints and investment-cash flow sensitivity. This result supports the research of S. Chen and H. Chen (2012). This condition occurs because non-financial companies in Indonesia have a greater proportion of external funding than equity in the use of funding sources. The level of debt used in companies in Indonesia tends to be high due to the concentration of company share ownership in Indonesia. Thus, companies prefer to use external funding in the form of debt compared to equity because debt will not reduce the control that can be exercised by shareholders and will not dilute the wealth of the company's founder. Debt funding also provides corporate profits in the form of a tax shield because debt interest is tax deductible. For companies operating in a country with a progressive 
tax rate such as Indonesia, the tax deduction from debt interest will be very profitable. According to Brigham and Houston (2011), companies that grow rapidly must use more external capital. Development costs for issuing shares are greater than the issuance of debt securities which encourage companies to rely more on debt. Small companies are more likely to rely on shortterm debt than long-term debt because of lower costs. Debt is an alternative source of corporate funding when its use in the right proportion will benefit the company compared to using company equity. The use of debt in funding will benefit the company compared to its capital, but the use of high debt will generate interest costs that can lead the company to a default position when the company has difficulty developing obligations. Therefore, the company's funding decision in determining the source of funding will have different effects or consequences depending on the choice of funding source. Based on the results of the study, the cash holding was positively associated with a significance of 0.05 . This result is interpreted if the holding cash increases by 1 percent, then the average capital expenditure realized by non-financial companies will increase by 0.021 . This research is in line with the results of the research by Prameswara (2012) which examined non-financial companies in Indonesia. Statistically, the effect of CASH_TA on CAPEX whose correlation coefficient is less than 0.05 is not very strong. This shows that the investment of Indonesian non-financial companies is realized at a moderate level, with the company's expectations being sufficiently established so that the investment aggressiveness is carried out at controlled limits. The use of internal funding to invest is also possible for companies with large profitability so that they will use relatively small debt. Reffering on the pecking order theory, companies in investing tend to prefer internal funding over external funding because of the asymmetrical information that increases external funding costs (Myers \& Majluf, 1984). Another reason is that internal funding is easier to obtain and tends to be safe, so that the company prioritizes internal financing through the availability of cash and also reduces the level of debt; however, the results in this study are in line with the assumption of the pecking order theory which states that companies that have high internal funding will tend to use external funding. This result means that companies reduce their use of external funding in investing. This shows that companies use cash holding to reduce external funding needs.

The results of this study indicate that external funding has a positive effect on a significant level of 10 percent. Based on the results of the study, it was shown that when external financing increased by 1 percent, the average capital expenditure realized by non-financial companies would increase by $1.41 \mathrm{E}-06$. This has an inverse relationship with Kim's research (2014). These results support the results of Prihatmoko's (2013) study which states that companies that use debt more tend to have relatively high investment-cash flow sensitivity, which implies that the use of external funding can be a mechanism that can increase investment. The use of external financing will certainly provide additional funds for the company to realize investment because the purpose of the company owes is indeed to increase its funding capabilities. By looking at the positive influence of 1.41E-6, if the company uses external funding the level of investment-cash flow sensitivity can increase; however, if the use of external funding is too large, it will disrupt the company to invest. The use of funding sources in realizing investment can use internal funding and external funding, both of which have substitution relationships. These results indicate that external funding can be used as a substitute for internal funding in financing investments. In deciding which investment to choose, always consider the amount of profit to be obtained by taking into account the time value of money (Saragih and Nugroho, 2014). The choice of investment is related to the cost of capital use which is the cheapest cost of capital; therefore, to maximize corporate value and maximize the wealth of shareholders, companies need to plan well in managing funding sources in investing. When faced with variations in spending, management needs to strive to fulfill a certain goal regarding the balance between the amount of external funding and internal funding. Funding decisions that are carried out inaccurately will result in fixed costs in the form of high capital costs and can result in the profitability of the company. This also means reducing the prosperity of shareholders. Companies still need to have a cash holding rate so that they can still fulfill their obligations and make investments when economic conditions are volatile. Also, companies can also balance the use of internal funding and appropriate external funding so that it is sufficient to finance operations and investments. External funding can also be used as a substitute for sources of funds in realizing investment. For companies with a low level of use of external funding, it is expected to be able to take advantage of the willingness of cash to invest in profitable projects whereas companies with the use of high external funding can pay attention to the nominal cash level they have to maintain debt repayment inaction.

\section{Conclusion}

This study has provided empirical evidence that in non-financial public companies in Indonesia for ten years there was a positive and significant cash holding effect on investment-cash flow sensitivity. Also, external financing had a negative and significant effect on investment-cash flow sensitivity. A significant positive effect between cash holding on capital expenditure identified investment-cash flow sensitivity to cash holding of 0.021 percent in non-financial companies in Indonesia. The results of this study has presented that the positive relationship between the cash holding and capital expenditure indicates that non-financial companies in Indonesia in investing tend to use the cash holding they have. By looking at the positive influence on external funding, then if the company uses external funding the level of investment-cash flow sensitivity can also increase. Non-financial companies in Indonesia use external funding in realizing their investments because the purpose of the company owes is indeed to increase their funding capabilities. The absence of a significant relationship between financial constraints and investmentcash flow sensitivity occurs because non-financial companies in Indonesia have a higher proportion of external funding usage than equity in the use of funding sources. 


\section{References}

Almeida, H., \& Campello, M. (2010). Financing frictions and the substitution between internal and external funds. Journal of Financial and Quantitative Analysis, 45(3), 589-622. DOI: 10.1017/S0022109010000177

Almeida, H., Campello, M., \& dan Weisbach, M. (2004). The cash flow sensitivity of cash. Journal of Finance, 59(4), 17771804.

Bao, D., Chan, K. C., \& Zhang, W. (2012). Asymmetric cash flow sensitivity of cash holdings. Journal of Corporate Finance, 18(4), 690-700.

Bates, T., Kahle, K., \& Stulz, R. (2009). Why do U.S. firms hold so much more cash than they used to?. Journal of Finance, 64 (5), 1985-2021.

Bodie, Z. (2009). Investments. Tata McGraw-Hill Education.

Brealey, R. A., Myers, S.C., \& Allen, F. (2006). Corporate Finance 8th edition. New York: McGraw-Hill Companies.

Brigham, E., \& Houston, J, F. (2011). Fundamentals of. Financial Management: Edisi 11. Jakarta: Salemba Empat.

Chen, H., \& Chen, S. (2012). Investment-cash flow sensitivity cannot be a good measure of financial constraints: Evidence from the time series. Journal of Financial Economics, 103(2), 393-410.

Cleary, S. (1999). The relationship between firm investment and financial status. Journal of Finance, 54(2), 673-692.

Degryse, H., \& De Jong, A. (2006). Investment and internal finance: Asymmetric information or managerial discretion?. International Journal of Industrial Organization, 24(1), 125-147.

Denis, D., \& Osobov, I. (2008). Why do firms pay dividend? International evidence on the determinants of dividend policy. Journal of Financial Economics, 89(1), 62-82.

Fahmi, I. (2013). Pengantar Manajemen Keuangan: Teori dan Soal Jawab. Bandung: Alfabeta.

Fazzari, S. M., Hubbard, R. G., \& Petersen, B.C. (1988). Financing constraints and corporate investment. Brooking Papers on Economic Activity, 1, 141-195. DOI: 10.2307/2534426

Gilchrist, S., \& Himmelberg, C.P. (1995). Evidence on the role of cash flow for investment. Journal of Monetary Economics, $36(3), 541-572$.

Gujarati, D. N. (2009). Basic Econometrics 5th edition. New York: The McGraw-Hill Companies.

Hennessy, C. A., \& Whited, T. M. (2007). How costly is external financing? Evidence from a structural estimation. Journal of Finance, 62(4), 1705-1745.

Kaplan, S. N., \& Zingales, L. (1997). Do investment-cash flow sensitivities provide useful measures of financing constraints?. The Quarterly Journal of Economics, 112(1), 169-215.

Kim, T. N. (2014). The impact of cash holding and external financing on investment-cash flow sensitivity. Review of Accounting and Finance, 13(3), 251-273. DOI: 10.1108/RAF-09-2012-0080

Lang, L., Ofek, E., \& Stulz, R.M. (1996). Leverage, investment, and firm growth. Journal of Financial Economics, 40(1), 3-29.

Lee, Y., \& Song, K. R. (2010). Financial crisis and corporate cash holdings: evidence from east Asian firms. European Financial Management Association Symposium. Renmin University, Beijing, China.

Myers, S.C., \& Majluf, N. (1984). Corporate financing and investment decisions when firms have information that investors do not have. Journal of Financial Economics, 13(2), 187-224.

Moyen, N. (2004). Investment-cash flow sensitivities: constrained versus unconstrained firms. Journal of Finance, 59 (5), 20612092.

Prameswara, R. D. (2012). Friksi Pendanaan dan Substitusi antara Pendanaan Internal dan Eksternal pada Perusahaan Constrained dan Unconstrained Periode 2006-2010. Depok: Fakultas Ilmu Sosial dan Ilmu Politik Universitas Indonesia.

Prihatmoko, B. (2013). Sensitivitas Investasi Terhadap Arus Kas pada Perusahaan Manufaktur di Indonesia. Depok: Fakultas Ekonomi Universitas Indonesia.

Ramadhan \& Nugroho (2017). The Analysis of Corporate Diversification and Cash Holding: A Study on Non-Financial Comapnies Listed in the Indonesian Stock Exchange during the Period of 2006-2015. Advances in Social Science, Education and Humanities Research, 167, Atlantis Press, 33-41. DOI: 10.2991/icaspgs-icbap-17.2017.10

Saragih, F. D., \& Nugroho, B.Y. (2014). Dasar-Dasar Keuangan Internasional. Depok: Rajawali Pers.

Tobin, J. (1969). A general equilibrium approach to monetary theory. Journal of Money, Credit and Banking, 1(1), 15-29.

Whited, T. M. (1992). Debt, Liquidity Constraints, and Corporate Investment: Evidence from Panel Data. Journal of Finance, $47(4), 1425-1460$.

Whited, T. M., \& Wu, G. (2006). Financial constraints risk. Review of Financial Studies, 19(2), 531-559.

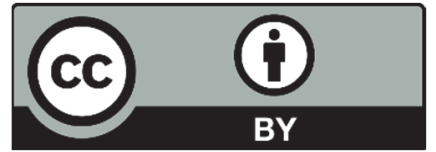

(C) 2020 by the authors; licensee Growing Science, Canada. This is an open access article distributed under the terms and conditions of the Creative Commons Attribution (CC-BY) license (http://creativecommons.org/licenses/by/4.0/). 